\title{
Quasi-Hadamard product of some uniformly analytic and $p$-valent functions with negative coefficients
}

\section{NicoletA BREAZ and RABHA M. EL-ASHWAH}

\author{
ABSTRACT. \\ In this paper we study the quasi-Hadamard product between some $p$-valent and uniformly analytic functions \\ with negative coefficients defined in connection with uniformly starlikeness and uniformly convexity.
}

\section{REFERENCES}

[1] Bharati, R., Parvathan, R. and Swaminathan, A., On subclasses of uniformly convex functions and coresponding class of starlike functions, Tamkang J. Math., 28 (1997), 17-32

[2] Chen, M. P., Irmak, H. and Srivastava, H. M., Some multivalent functions with negative coefficients defined by using differential operator, PanAmer. Math. J., 6 (1996), No. 2, 55-64

[3] El-Ashwah, R. M., Aouf, M. K., and Breaz, N., On quasi-Hadamard product of p-valent functions with negative coefficients defined by using a differential operator, Acta Univ. Apulensis Math. Inform., 29 (2011), 61-70

[4] Frasin, B. A., Quasi-Hadamard product of certain classes of uniformly analytic functions, General Mathematics, 16 (2007), No. 2, 29-35

[5] Kanas, S. and Wisniowska, A., Conic regions and k-uniform convexity, J. Comput. Appl. Math., 105 (1999), $327-336$

[6] Kanas, S. and Wisniowska, A., Conic regions and k-uniform starlike, Rev. Roumaine Math. Pures Appl., 45 (2000), No. 4, 647-657

[7] Owa, S., On certain classes of p-valent functions with negative coefficients, Simon Stevin, 59 (1985), 385-402

[8] Sălăgean, G. S., Hossen, H. M. and Aouf, M. K., On certain classes of p-valent functions with negative coefficients. II., Studia Univ. Babes-Bolyai, 69 (2004), No. 1, 77-85

[9] Sekine, T., On quasi-Hadamard products of p-valent functions with negative coefficients in Univalent Functions, Fractional Calculus, and Their Applications, (H. M. Srivastava and S. Owa Eds.), Holsted Press (Ellis Horwood Limited, Chichester), John Wiley and Sons, New York, Chichester, Brisbane and Toronto, 1989, pp. 317-328

\author{
"1 DeCEMbrie 1918" University OF Alba IUlia \\ Nicolae IORGa 11-13, 510009 Alba IUlia, Romania \\ E-mail address: nbreaz@uab.ro \\ DEPARTMENT OF MATHEMATics \\ MANSOURA UNIVERSITY \\ FACULTY OF SCIENCE (DAMIETTA BRANCH) \\ NEW DAMIETTA 34517, EGYPT \\ E-mail address: $r_{-}$elashwah@yahoo.com
}

DEPARTMENT OF MATHEMATICS AND COMPUTER SCIENCE

Received: 01.02.2013; In revised form: 16.09. 2013; Accepted: 30.09.2013

2010 Mathematics Subject Classification. 30C45.

Key words and phrases. Uniformly analytic, $p$-valent, Hadamard product.

Corresponding author: Nicoleta Breaz; nbreaz@uab.ro 